Published in Journal of Consumer Behaviour, 2019, vol. 18, no. 3, pp. 190-204 which should be cited to refer to this work.

DOI : $10.1002 / \mathrm{cb} .1757$

\title{
The Role of Personal Relevance in the Value Creation Process of Edutainment Consumption
}

\begin{abstract}
This paper explores the value creation process in an edutainment context. It attempts to capture the dual, differential value creation processes through two pathways, namely, affective and cognitive. Results revealed that affective and cognitive values not only increase customer satisfaction, but also enhance consumer well-being. Moreover, contrary to conventional belief asserting that value creation is a universal process, this study finds that those who had higher personal relevance with the edutainment context experienced more intense emotional and intellectual values which in turn, enhanced both their satisfaction, well-being, and revisit intention. Results suggest that marketers need to re-think their engagement strategy in order to create both emotional and intellectual value for customers.
\end{abstract}

Keywords: Co-creation, Edutainment, Consumer Experience, Well-being, SEM 


\section{The Role of Personal Relevance in the Value Creation Process of Edutainment Consumption}

\section{INTRODUCTION}

Consumers increasingly seek complex experiences that combine both learning and discovering. This is evident in recent trends, which showed that 1) younger generations prioritize experience over material goods (Eventbrite Survey, 2014); 2) the online learning industry was worth over USD 100 billion in 2015 (Forbes, 2015); and 3) the growing need for more mindful and meaningful travel experience (Tribe and Liburd, 2016). Edutainment consumption, which refers to an experience containing both entertainment and education content with which consumers interact and from which they derive subjective responses (Addis, 2005), caters to the growing demand for experiences that are both entertaining and educational. Existing literature directly examining edutainment in the consumption context is limited (Addis, 2005; Balloffet et al, 2014). One reason could be due to the fuzzy distinction between an edutainment and an experiential consumption, which could yield both emotional and cognitive values. For example, an experience in a shopping mall consists of hedonic, cognitive, and utilitarian dimensions (Haytko and Baker, 2004); museum visitors experience both hedonic and cognitive value (Chen, 2009; Sheng and Chen, 2012; Joy and Sherry, 2003). But the most common experiential consumption such as retailing, dining, and traveling are considered entertainment services with no intended educational purpose.

By definition, edutainment consumption must contain both fun and learning. One example would be the popular blended theme park-museum which exists around the world. Theme parks are defined as "an aggregation of themed attractions, including architecture, landscape, rides, shows, food services, costumed personnel, and retail shops" (Heo and Lee, 2009). Museums are defined as "non-profit-making institutions that serve to acquire, conserve, research, communicate and exhibit, for purposes of study, education and enjoyment, 
material evidence of people and their environment" (International Council of Museums, 2007). While both activities are regarded as important selection criteria for a travel destination (Kozak and Rimmington, 1999), conventional wisdom would put them in a very different genre of activity. Interestingly, as both museums and theme parks try to enhance customer satisfaction by creating more unique and 'sticky' (i.e., memorable) experiences, theme parks seek to include more cultural content and museums begin to incorporate more interactive elements to enhance their entertainment value, which subsequently gave rise to this hybrid form of edutainment consumption (Balloffet et al, 2014).

The current study offers a unique contribution to the extant consumer value literature by investigating value creation in an edutainment context, namely, a biblical theme parkmuseum. In past studies, the utilitarian aspects of consumption have often been linked to cognition and cognitive information processing (Babin et al, 1994). In general, cognitive experience seems to be equated with instrumental, utilitarian perspective. The current study proposes that the cognitive value derived from edutainment is not utilitarian. The act of learning is in and of itself valuable irrespective of what is actually being learnt. The cognitive value from edutainment is not utilitarian because the educational content may not be used by the consumer outside of the edutainment context. In this regard, the current study conceptualizes cognitive value derived from an edutainment experience as intellectual value. More specifically, the current study focuses on one aspect of intellectual value, i.e., the value of gaining new knowledge or perspective about a specific subject, which is rooted in the psychological need for self-growth and self-enhancement (Arnould and Price, 1993; Celsi et al., 1993; Sheldon et al, 2001), and proposes a measure that can capture this knowledge dimension of intellectual value.

Moreover, the extant value creation literature has often examined how an external context would induce varying consumer value such as emotional and cognitive values, and in 
turn, would impact consumer outcomes such as satisfaction and loyalty (e.g., Bendapudi and Leone 2003; Gallarza, Fayos Gardó and Calderón García, 2016; Mathwick, Malhotra, \& Rigdon, 2001; Sweeney \& Soutar, 2001). This line of research seems to suggest that value derived from an external context (e.g., shopping mall, restaurant, etc.) would invariably enhance consumer outcomes. But recent consumer research found that a consumer's value perception and appraisal is a need-based process (Brendl, Markman, and Messner 2003; Chartrand, Huber, Shiv, and Tanner 2008; Laran, Janiszewski, and Cunha 2008). Consequently, the current study proposes that value transfer (i.e., value created in a consumption experience) is not universalistic, rather, it is contingent on individual difference (e.g., personal relevance).

The outline of this paper is as follows. The paper begins with a literature review on value creation in edutainment, emotional and intellectual value, customer satisfaction and customer well-being, and personal relevance. Specifically, in the conceptual framework discussion, this study proposes that visitors' interaction with the park will generate both emotional and intellectual value. This value will in turn affect customer satisfaction, customer well-being, and revisit intention. In addition, in line with the contingent view of value transfer, this study hypothesizes that personal relevance will moderate the value creation process. Next, the hypotheses development section explains and specifies the proposed chain of relationships among the constructs. The methodology section details the sample, procedure, analyses, and results. Finally, a general discussion specifies theoretical and managerial implications as well as limitations and future research.

\section{LITERATURE REVIEW}

2.1 Value creation in edutainment

Behavior often depends on an interaction between the environment and the person. 
The environment refers to "anything that is external to the person whose behavior is being explained and that can be measured independently of that person" (Russell and Mehrabian, 1976). Based on the S-O-R framework (Figure 1) (Jacoby, 2002; Mehrabian and Russell, 1974), environmental stimulus will be processed by the emotive and cognitive systems of an individual (organism), which will then become some unobservable internal experience such as impressions, images, knowledge, and feelings. Subsequently, internal experience will generate responses which can take different forms including attitude, liking, preference, and more overt responses such as purchase or repurchase (Jacoby, 2002). Similarly, Addis (2005) conceptualizes edutainment as a market offer that contains education and entertainment content with which the consumer interacts to derive the edutainment experience and subjective response.

Although the edutainment conceptualization by Addis (2005) has yet to be empirically examined, the S-O-R framework has been widely adopted by marketing and consumer researchers, especially for the examination of how a servicescape affects customer's emotional response and customer evaluation across consumption contexts such as shopping, dining, hotel stay, and cruising (e.g., Jani and Han, 2015; Kim and Moon, 2009; Correia Loureiro et al, 2013). Past research emphasizes on emotional value in consumption because the consumption are often viewed as either utilitarian or hedonic. In the past, experiential consumption had been equated with emotion-laden experiences filled with fantasies, feelings, and fun (Holbrook and Hirschman, 1982). On the contrary, the utilitarian aspects of consumption are often linked to cognition and cognitive information processing (Babin et al, 1994). In general, cognitive experience seems to be equated with an instrumental, utilitarian perspective. For example, utilitarian shopping value is obtained when a shopper successfully finds and/or purchases what he/she planned before the shopping trip (Babin et al, 1994).

Contrary to the common perspective on cognitive experience, the current study 
proposes that the cognitive value derived from edutainment is not utilitarian. The kind of cognitive value derived from edutainment is in line with extant conceptual and qualitative research, which suggests that people can interact with their surrounding cognitively and derive intrinsic as opposed to instrumental value (Holbrook and Hirschman, 1982). Examples of cognition-laden intrinsic value are abundant in qualitative research: museum-goers getting information on a piece of art or learning about the history of art (Chen, 2009; Joy and Sherry, 2003), river-rafting participants gaining a sense of personal growth through learning new whitewater jargon from the river guides (Arnould and Price, 1993), and shoppers gaining general knowledge about fashion (Haytko and Baker, 2004).

\subsection{Customer satisfaction and customer well-being in edutainment}

Due to the dual purpose of edutainment, the satisfaction it derives should reflect both the entertainment and educational expectations. On the one hand, consumers would evaluate an edutainment experience with typical customer satisfaction construed as the affective response of service consumption (Oliver and Bearden 1985). On the other hand, consumers would evaluate the same experience through an educational lens, which in turn would generate a sense of well-being.

Past psychology literature examining satisfying events found that enhancement and growth are crucial components of events that are seen as "most satisfying" (Sheldon et al, 2001). Enhancement and growth needs are two intrinsic, high level goals proposed in the Maslow's theory of personality (1954). Events that fulfill these goals would bring about a sense of subjective well-being, which refers to "an overall evaluation of the conditions of one's life" (Burroughs and Rindfleisch, 2002). Subjective well-being arises from a sense of self-enhancement and self-growth, and is evident in extended service experienecs such as river-rafting (Arnould and Price, 1993) and sky-diving (Celsi et al., 1993). 


\section{CONCEPTUAL FRAMEWORK}

The conceptual framework of the current study is depicted in Figure 2. In line with S$\mathrm{O}-\mathrm{R}$ and the edutainment as interaction conceptualization, attributes in the consumption environment will influence consumers' perceived value, which will affect consumer outcomes such as evaluation of the consumption experience (see Figure 2). Ample research provides support for the chain of relationships as specified above (e.g., Babin et al, 1994; Sweeney and Soutar, 2001; Zeithaml, 1988). While consumers' interaction with the environment has been shown to create emotional value, the cognitive result manifested as intellectual value had been neglected.

Building on S-O-R, attributes in the theme park-museum represent the environmental cues with which the individual will experience with regard to both the emotive and cognitive systems. The value attached to the experience will consist of both emotional and cognitive underpinnings, which are referred to as emotional value and intellectual value, respectively. Finally, value derived will affect customer satisfaction.

\subsection{Edutainment performance}

Servicescape literature identifies 'ambient conditions' (i.e., background characteristics such as lighting, music, etc.), 'spatial layout and functionality' (i.e., equipment and furnishings, performance, utility, etc.), and 'signs, symbols and artifacts' (i.e., labels, signage) as the three dimensions of physical environment (Bitner, 1992). The dimensions have been applied in restaurants, SPAs, and hotel contexts (Kim and Moon, 2009). These service settings a have more or less uniform servicescape within one establishment. For example, even for a themed restaurant, the three dimensions should be consistent to reflect a single theme in a confined space. This uniformity, however, cannot be applied to the theme park-museum being examined in this study. The park-museum occupies a more dispersed and diversified physical 
environment with both indoor and outdoor attractions with various biblical themes. As a result, each of the three dimensions vary considerably. In this case, it is more appropriate to identify distinctive features that can holistically represent the specific service setting (Wakefield and Blodgett, 1994). As a result, the edutainment performance variable for the current study is more appropriately conceptualized as a holistic perception of the park's physical setting and feature.

\subsection{Consumer value}

Emotional value is derived from an internal emotive experience and is defined as "the utility acquired as a result of a product's or service's ability to arouse feelings or affective states" (Seth et al., 1991; Sweeney and Soutar, 2001). Specifically, this value reflects the emotional outcome of a person's interaction with the immediate surroundings, which is an emotive internal experience.

Intellectual value. Drawing on the emotional value literature (Seth et al., 1991; Sweeney and Soutar, 2001), this study defines intellectual value as the utility acquired as a result of a product's, a service's or an experience's ability to stimulate the visitor's intellect. Intellectual value reflects the cognitive outcome of a person's interaction with the immediate surroundings, which is a cognitive internal experience. Intellectual value encompasses experiences at all stages of consumption as previously stated and is the psychological outcome that one experiences after one's interaction with the environment.

Examples of intellectual value are abundant in the qualitative account of experiencerich consumption: museum-goers getting information about a piece of art or the history of art (Chen, 2009; Joy and Sherry, 2003), river-rafting participants gaining a sense of personal growth through learning new jargon from river guides (Arnould and Price, 1993), and shoppers gaining general knowledge about fashion (Haytko and Baker, 2004). Although 
Arnould and Price (1993) reported in their findings that personal growth, which is measured by items such as learning new things and mastering new skills, is an important determinant for an extraordinary experience (i.e. river-rafting), the construct of personal growth is specific to river-rafting and other extreme sports. The intellectual value suggested in the current study is intended to be generalizable to an interactive but less extreme consumption context. At the same time, to capture the aspect of intellectual value that is likely derived from an edutainment context with an intended educational purpose, the intellectual value of this study focuses on intellectual value derived from gaining new knowledge or perspective about a specific subject that is evident in previous research (Arnould \& Price, 1993; Chen 2009; Haytko and Baker, 2004; Joy and Sherry, 2003).

\subsection{Customer satisfaction v. customer well-being}

Customer outcomes from an edutainment experience will be manifested in customer satisfaction and customer well-being and reflect the consumer's expectation for entertainment and education from the edutainment service.

Customer satisfaction refers to the affective response towards a service consumption as a result of the expectation versus actual experience comparison as posited by the disconfirmation paradigm (Oliver and Bearden 1985). Unlike the customer satisfaction construct, customer well-being has been construed quite differently in both psychological and marketing literature.

Customer well-being emerges out of the subjective well-being (SWB) concept, which is conceptualized as the extent to which an individual views his or her quality of life (Diener, Oishi, \& Lucas, 2002) and is considered a multi-faceted construct pertaining largely to positive affect, lack of negative affect, happiness, and life satisfaction (Andrews \& Withey, 1976; Lucas, Diener, \& Suh, 1996). "There is probably no other goal in life that commands 
such a high degree of consensus" (vii, Frey \& Stutzer, 2002). As a result, there is a plethora of factors that contribute to Subjective Well-Being (SWB). For example, culture (Veenhoven, 1993), religious activities and exercise (Mochon, Norton, \& Ariely, 2008), and marriage and family (Easterlin, 2003) have all been identified as indicators for happiness and life satisfaction. Extant consumer behavior literature also identified a range of factors that play a role in impacting a customer's well-being. For example, prosocial spending (e.g., donation) generates well-being because it fosters strong social ties crucial for happiness (Diner, Oishi, \& Lucas, 2003) and facilitates positive self-presentation (Schervish \& Szanto, 2006); material possessions (e.g., a car, a bigger house, etc.) score worse than experiential purchases (e.g., a vacation, a theatrical play, etc.) when it comes to generating the subjective well-being of a customer (e.g., Frank, 1985; Howell \& Hill, 2009; Nicolao, Irwin, \& Goodman, 2009; Van Boven \& Gilovich, 2003). Related to the latter stream of research is studies that showed that the "most satisfying" experiences are those which enhance the self and enable an individual to grow, such as education (Sheldon et al, 2001). In this research, customer well-being is defined as a sense of self-enhancement or self-growth reflected in knowledge acquisition and perspective gaining, which has been identified in other forms of consumption contexts in consumer behavior research (Arnould \& Price, 1993; Chen 2009; Haytko and Baker, 2004; Joy and Sherry, 2003).

\subsection{Revisit intention}

Revisit intention is an important indicator of consumer loyalty (Zeithaml et al., 1996). It has long been established that higher customer satisfaction leads to higher repeat purchase and repeat visitation (Kim and Moon, 2009; Zeithaml et al., 1996). The link between customer well-being and revisit intention, however, remains unclear. It can be argued that consistent with research on customer benefit expectations formation, a positive experience 
with a specific service (or service provider) should increase the likelihood of one choosing the same service again. Since a sense of self-enhancement and self-growth is a positive experience, customer well-being derived from an edutainment should also increase revisit intention.

\subsection{Individual difference: Personal relevance}

Value creation and how value translates into positive consumer outcome has been shown to be a universal mechanism: as consumer value increases so does consumer outcome such as satisfaction irrespective of individual differences (e.g., Babin et al, 1994; Sweeney and Soutar, 2001). In the typical study, people are induced into positive or negative feelings in a supposedly unrelated task. Then, they are asked to evaluate some target people or objects. The consistent finding is that whereas positive feelings enhance evaluation of the target, negative feelings hinder evaluation (e.g., Frijda 1986; Schwarz 1990). Recent research, however, posits that value from experience may not invariably translate to positive evaluation. Recent findings suggest that a consumer's value perception and appraisal is a need-based process (e.g., Brendl et al, 2003; Laran et al, 2008). Product evaluation and choice depend on the extent to which a product is expected to be an effective means for achieving an active consumer goal (c.f., Van Osselaer and Janiszewski 2012). Similarly, some research also suggests that whether or not transient feelings affect judgment is dependent on the relevance of the feeling to the judgment at hand (Gorn, Goldberg, and Basu 1993; Pham 1998). Various individual differences have been shown to have an impact on the type of benefits perceived, and in turn, lead to differential perceived value of a product (Hunt, Radford, \& Evans, 2013). This contingent view suggests that people do not invariably use feelings as bases for their judgments or evaluations. Transient feelings will only be passed onto judgment and evaluation when these feelings are congruent with the underlying motives salient at the time. Some research supported the contingent view of value transfer by showing that the positive effect of 
consumer involvement is dependent on an individual's motivation (Troye and Supphenllen 2012). In particular, only people who were motivated to cook (i.e., people who liked cooking) thought that their dishes tasted better, but this was not the case for people who were not motivated to cook. Taken together, these studies suggest that value transfer is contingent on individual motivation.

Personal relevance to a consumption type or context can vary due to different levels of needs for the specific value endowed, which in turn may affect the appraisal of the value. Personal relevance refers to the variation in an individual's level of motivation to seek a certain value which would then affect the appreciation of the value (Troye and Supphenllen, 2012). Moreover, it is also found that people form different expectations even for the same experience (e.g., museum visit, Sheng and Chen, 2012) which in turn, would influence how they evaluate the outcome. In the context of the current study, personal relevance is operationalized as the religious background of the consumer because the edutainment setting is a biblical themed park-museum. More specifically, people with a bible-based religion are believed to possess more spirituality (i.e., someone who finds personal transcendence, connectedness, meaning, and life direction with belief in god or Higher Power; Zinnbauer et al., 1997). Spirituality has been shown to be a source of motivation for consumption such as travel (Moal-Ulvoas \& Taylor, 2014).

\section{HYPOTHESES DEVELOPMENT}

According to S-O-R (Jacoby, 2002), customer responses can be categorized into inward and outward. Outward responses are the more commonly studied elements of customer satisfaction with a company and customer loyalty, whereas inward responses can include changes in attitudes and beliefs. Changes in attitudes and beliefs are often associated 
with self-enhancement and self-growth, which contributes to a sense of subjective well-being (Arnould and Price, 1993; Sheldon et al, 2001).

While outward responses manifested in consumer outcomes, such as loyalty and repurchase, are key performance measures and are of paramount importance, inward responses are often overlooked. Inward responses are not expected outcomes for the majority of services that are either utilitarian or hedonic in nature. Yet, consumer researchers acknowledged that it is important to provide consumption promoting individual well-being (Mick et al, 2012). The current study hypothesizes that due to the dual purpose of edutainment, the customer responses it generates should reflect both entertainment and educational expectations. Consequently, consumers would evaluate an edutainment experience with in terms of customer satisfaction construed as the affective response of service consumption. In addition, they would assess the educational expectation which is then manifested as customer well-being. Customer well-being refers to a sense of selfenhancement and self-growth and it can be viewed as a subjective response resulting from the consumer's interaction with the educational content of the edutainment service (Addis 2005). Drawing on the intersection of experiential consumption and edutainment research, the current study extends previous research by examining experience within the S-O-R framework in a new and increasingly important consumption context - edutainment. The following hypotheses are proposed:

H1: Edutainment performance will positively influence a) emotional value and b) intellectual value.

H2: a) Emotional value and b) intellectual value mediate the influence of edutainment performance on customer satisfaction.

H3: a) Emotional value and b) intellectual value mediate the influence of edutainment performance on customer well-being. 
The S-O-R framework suggests that the chain reaction from encountering a stimulus to internal experience to response is an automatic process. This proposition has significant implications for marketers because internal experience essentially is the value derived from the consumption experience and the resultant responses signify how value created internally will be transferred to the company represented by an increase in company liking or preference. On the one hand, this universalistic view of value creation and transfer is supported by past consumer research, which has repeatedly found that value from experiential consumption, such as shopping and dining, are positively related to consumer satisfaction (e.g., Babin et al, 1994; Sweeney and Soutar, 2001). On the other hand, recent research show evidence that value from experience does not invariably translate to evaluation. Findings from these studies suggest that a consumer's value perception and appraisal is a need-based process (e.g., Brendl et al, 2003; Laran et al, 2008). Specifically, research showed that whether or not experiential value transfer will take place is dependent on an individual's motivation as well as the valence of the value (Troye and Supphenllen, 2012). In particular, the experience of cooking with a cooking kit only enhanced the perception of the brand for people who saw cooking as personally relevant. However, this was not the case for people who were not motivated to cook. In this regard, this stream of research, which shows that value transfer is contextual, is more in line with the service-dominant logic, which posits that "value is always uniquely and phenomenologically determined by the beneficiary' (Vargo and Lusch, 2008).

There are two conflicting predictions as to whether or not emotional value and intellectual value obtained from the consumption experience will enhance customer satisfaction and customer well-being. In line with S-O-R theory, both emotional and intellectual value should increase customer satisfaction and customer well-being irrespective of individual motivation. But if the influences of emotional and intellectual value on customer 
outcome are, like it is suggested by the service-dominant logic, dependent on individual differences in motivation, then differential impacts of each value on customer satisfaction and customer well-being would be observed.

One individual motivation relevant to the current study's context is the religious background of the individual visitor. This is because the theme park-museum where data were collected is based on Christianity and the bible. For example, its core attraction is its rendition of Noah's Ark, which is advertised as the world's first full-scale Ark replica; there is an Ark Garden which consists of statues of all of the pairs of animals as mentioned in the bible; there is also an interactive Ark Expo which lets visitors experience Noah's spiritual journey as well as how he would have constructed the Ark with tools and materials available at the time. As a result, visitors who belong to a Christian bible-based religion may feel more connected with the attraction and exhibition provided in this park-museum. Since the religious groups to which the majority of the Hong Kong population belong were those rooted in China (i.e., Buddhism, Taoism, Confucianism; roughly over $80 \%$ of the population) and those introduced from outside such as the Roman Catholic and the Protestant (12\%) and Muslim, Hinduism, Sikh, and Jewish (6\%) (Hong Kong Statistics Department, 2016), the current study used a self-report measure of religious affiliation to determine the personal relevance of an individual with the park-museum. More specifically, people who indicate that they are affiliated with Christianity would possess a higher personal relevance (higher motivation) for their park visits than those who either are not acquainted with any religion or those who are affiliated with a religion other than Roman Catholic or Protestant (e.g., Buddhism, Muslim, etc.).

H4a: Personal relevance will moderate the relationship specified in H2. Specifically, the effects of both emotional (H2a) and intellectual value (H2b) on customer satisfaction should be more prominent for people with high (vs. low) personal 
relevance.

H4b: Personal relevance will moderate the relationship specified in H3. Specifically, the effects of both emotional (H3a) and intellectual ( $\mathrm{H} 3 \mathrm{~b})$ value on customer wellbeing should be more prominent for people with high (vs. low) personal relevance.

It is well-established in the marketing literature that a satisfied customer will be more likely to return (e.g., Correia Loureiro and Kastenholz, 2011). For example, in the value creation chain of relationships, it has been shown that enjoyment derived from shopping is directly related to loyalty (Gallarza, Fayos Gardó and Calderón García, 2016). Since customer satisfaction and customer well-being proposed in the current study are both attributable to the consumption experience, it follows that both types of satisfaction should increase revisit intention. Thus, the following is proposed:

H5: a) Customer satisfaction and b) customer well-being will positively influence revisit intention.

\section{METHODOLOGY}

\subsection{Data collection}

Data was collected at a theme park-museum in Hong Kong. This theme park-museum has a biblical theme and has both exhibitions and attractions on the property. Visitors were approached by researchers as they were exiting the park over two weekends. The survey was conducted using random sampling where each of the two researchers were instructed to approach every other person who exited the park through two turnstiles to which they were each assigned. Upon the individual's consent, an envelope containing the questionnaire and instructions was handed to them. They were instructed to fill out the questionnaire and mail it 
back within one week from the date they visited the park. They were also informed that if they were to return a completed questionnaire within one week, they would receive an fast food restaurant voucher worth HK\$30 (around US\$4). A total of 300 envelops were handed out: 185 questionnaires were returned within the time frame specified but six were incomplete. As a result, 179 questionnaires were included in the analysis (see Table 1 for respondent profiles).

\subsection{Measurement}

Table 4 provides a complete list of the scale items used to measure each variable in the conceptual model as well as their reliabilities. All variables, except for intellectual value and personal relevance, were either taken directly from an established scale or adapted to fit the current study's edutainment context. All items were rated on a 7-point scale ranging from " $1=$ Strongly Disagree" to "7 = Strongly Agree." The questionnaire also included demographic questions.

Edutainment performance $(\alpha=.88)$ was measured with a 4 -item scale from Kim and Moon (2009) adapted to the edutainment context. Emotional value $(\alpha=.95)$ was measured with a 5-item scale. Three items were taken from the emotional value scale from Sweeney and Soutar (2001). Two items, namely, "I am happy" and "I am content" were added to reflect the commonly used expression to describe positive emotional experience. Customer satisfaction $(\alpha=.94)$ was measured with a 3 -item scale adapted from Oliver and Bearden (1985).

Customer well-being $(\alpha=.93)$ was measured with a 4-item scale from Arnould and Price (1993) and Sheldon et al. (2001). Revisit intention $(\alpha=.92)$ was measured with a 3-item scale from Kim and Moon (2009).

Intellectual value was measured with a 5-item scale. The initial set of intellectual value consists of 31 items including elements that can be viewed in Table 2. This initial set of intellectual value was derived from the literature review on experiential and experience-rich 
consumption; more specifically, the list contains six items from Arnould and Price (i.e.

personal growth and renewal, 1993), four items from Chen (i.e. three for access value and one for possession value, 2009), 12 items from Novak, Hoffman and Yung (i.e. 4 for challenge and 8 for exploratory behavior, 2000), six items from Shoham, Rose and Kahle (i.e. three each for curiosity-arousal and adventure, 1998), and eight items from Unger and Kernan (i.e. four each for mastery and arousal, 1983). This initial list of items was presented to four experts (two faculty members and two doctoral students in the field of marketing) to evaluate whether items were representative of the intellectual value scale. Ten intellectual value items were classified as intellectual value by all four judges and were kept for further analysis. Seven items were categorized as intellectual value by at least three judges and were also retained because this met the acceptable agreement index of $75 \%$ (Hinkins, 1985). Thus, a total of 17 items representing intellectual value were submitted to exploratory factor analysis. Table 2 provides the list of initial items where the 17 items retained are bolded.

These 17 items were then included in a pilot study to assess reliability and face validity. Respondents were undergraduate students at three universities in Hong Kong. Each respondent was asked to write a brief description of their most recent theme park or museum visit. Then, they responded to the 17 intellectual value items. The objective of the description was to refresh the respondents' memory about their theme park or museum experience before assessing the scale items. A total of 120 surveys were collected (51\% female). All items were rated on a six-point scale ranging from " $1=$ Strongly Disagree" to " $6=$ Strongly Agree." An exploratory factor analysis was conducted on the 17 items. Results showed that these items belong to four components and each component and its corresponding items are presented in Table 3. Six items were excluded by the EFA analysis because their loadings were less than 0.7; consequently, the EFA output only included 11 items, each of which loaded on one of four principal components. Only component 1 and 2 have Eigen values of greater than 1. But, 
the first component alone accounted for $71.52 \%$ of total variance explained. As a result, the five items of the first component generated by the exploratory factor analysis were retained for the main study to assess intellectual value. The 5 items yielded a Cronbach's alpha of .95.

Personal relevance is operationalized as the religious background of the consumer because of the context of the current study, namely, a bible theme park-museum. In particular, respondents' religious background were identified with the aid of two questions in the questionnaire: "Do you have a religion?" and "Please indicate what is your religion." People who reported their religion as a bible-based one, namely, Christian or Catholic (common in Hong Kong), were put into the high personal relevance group. Those who indicated that they had no religion or belonged to non-bible-based religions (e.g., Buddhism and Taoism) were put into the low personal relevance group for the purpose of this study.

\subsection{Measurement model}

Following the two-step approach of structural equation modeling (Anderson and Gerbing 1988), a confirmatory factor analysis (CFA) was conducted to assess the measurement model. The CFA results are presented in Table 4.

Convergent validity was established because all items' factor loadings are high and significant at $\mathrm{p}<.01$. Moreover, the average variance extracted (AVE) from all variables are greater than the criterion of 0.5 , which indicates that the latent variable explained the majority of variance in the items (Fornell and Larcker, 1981). Discriminant validity among constructs was assessed by comparing the AVE of each construct with the square of the correlation estimates representing its correlation with other factors. As shown in Table 5, the AVE of each variable is higher than its squared correlation with other variables, which suggests that there is discriminant validity for all six constructs examined in this study. Finally, all global indicators but chi-square from the CFA shows indicates an acceptable measurement model fit. 
Specifically, CFI $=.99, \mathrm{NFI}=.98, \mathrm{IFI}=0.99, \mathrm{GFI}=0.83, \mathrm{RMSEA}=.07$, and $\mathrm{SRMR}=.04$, with $\chi^{2}(237)=454.12, p=0.00$. Even though a significant chi-square suggests a poor fit, the ratio between chi-square and the number of degrees of freedom is 1.92 , which is low and suggests that the measurement model has a good fit (Thomson et al, 2005). In summary, convergent validity, discriminant validity, and the adequate measurement model fit provide strong evidence that the measures used in this study are reliable and accurate.

\subsection{Structural model}

The estimated model fits the data reasonably well: $\mathrm{CFI}=.99 ; \mathrm{NFI}=.98 ; \mathrm{IFI}=.99$; $\mathrm{GFI}=.84 ; \mathrm{RMSEA}=.06 ; \chi^{2}(237)=403.17, p=0.00 ;$ the ratio between chi-square and the number of degrees of freedom is 1.7 .

Two mediation processes were proposed in the conceptual model and examined by SEM analysis (see Table 6). To establish mediation in SEM, it is necessary to show that the independent variable is positively related to the mediator and the mediator is positively related to the dependent variable. In this case, mediation is evident if edutainment performance is positively related to emotional value and intellectual value ( $\mathrm{H} 1 \mathrm{a}$ and $\mathrm{H} 1 \mathrm{~b})$ and that each value is positively related to customer satisfaction $(\mathrm{H} 2 \mathrm{a}$ and $\mathrm{H} 2 \mathrm{~b})$ and customer well-being ( $\mathrm{H} 3 \mathrm{a}$ and $\mathrm{H} 3 \mathrm{~b})$.

Parameter estimates showed that edutainment performance enhances both emotional $(\beta$ $=.78, t=10.35)$ and intellectual value $(\beta=.78, t=9.54)$; therefore, H1a and $\mathrm{H} 1 \mathrm{~b}$ are both supported. H2 hypothesized the first mediation process representing the relationship chain from edutainment performance to internal experience reflected in emotional and intellectual value, which in turn affects responses manifested in customer satisfaction. Parameter estimates suggested that both emotional and intellectual value mediate the effect of edutainment performance on customer satisfaction $\left(\beta_{\text {emotional-customer satisfaction }}=.73, t=8.78\right.$; 
$\beta_{\text {intellectual-customer satisfaction }}=.2, t=2.62$ ). Thus, $\mathrm{H} 2 \mathrm{a}$ and $\mathrm{H} 2 \mathrm{~b}$ are both supported. Next, $\mathrm{H} 3$ hypothesized the second mediation process describing the relationship chain from edutainment performance to internal experience reflected in emotional and intellectual value, which in turn affects responses manifested in customer well-being. Surprisingly, parameter estimates suggested that only intellectual value mediates the effect of edutainment performance on customer well-being $\left(\beta_{\text {intellectual-well-being }}=.64, t=5.43\right)$ but not emotional value $\left(\beta_{\text {emotional-well-being }}=.07\right.$, n.s. $)$. Thus, $\mathrm{H} 3 \mathrm{~b}$ is supported but $\mathrm{H} 3 \mathrm{a}$ is not.

Finally, H5 proposed that customer satisfaction and customer well-being would both increase revisit intention. Contrary to the prediction, however, only customer satisfaction has a positive impact on revisit intention $(\beta=.64, t=5.43)$ but not customer well-being $(\beta=.07$, n.s.).

\subsection{Moderating effects}

Hypothesis 4 proposes that personal relevance may accentuate the chain effect of edutainment performance on both emotional and intellectual value, which will result in higher customer satisfaction and customer well-being due to motivation. Personal relevance is operationalized as an individual's association with a bible-based religion. Whereas one who is associated with a bible-based religion (e.g., Catholic, Christian, etc.) was categorized as high in personal relevance, one who is not associated with a bible-based religion (e.g., not religious or affiliated with a non-bible based religion) was categorized as low in personal relevance. There were 97 (high personal relevance) and 82 (low personal relevance) cases in the respective groups.

A multi-group SEM analysis (Byrne, 2004) was conducted to test these moderation hypotheses (see Table 7 and 8). Table 7 shows the results of the multi-group comparison test. These results provided evidence for significant difference across the two personal relevance 
groups when the structural paths are set free (i.e., Model 2; $p<.05$ ). The path coefficients reported in Table 8 revealed that, as expected, for those who were in the high personal relevance group, the relationships between consumer value and customer outcomes were stronger (Emotional-Satisfaction: $\beta_{\text {low }}=.68$ vs. $\beta_{\text {high }}=.80$ and Intellectual-Well-being: $\beta_{\text {low }}$ $=.47$ vs. $\left.\beta_{\text {high }}=.66\right)$. Moreover, while emotional and intellectual value affect both customer satisfaction and well-being for those who were in the high personal relevance group, this is not the case for the low personal relevance group. For the low personal relevance group, there was a clear affective and cognitive route. In particular, emotional value increases customer satisfaction but intellectual value increases customer well-being. As a result, $\mathrm{H} 4$ was supported.

\section{DISCUSSION AND CONCLUSIONS}

\subsection{Contribution and research implications}

The current study builds on existing literature on the conceptualization of edutainment and provides empirical support for how consumers derive value from such consumption. In the past, edutainment was mostly examined in the context of education and was examined through experiential learning and in-class games (Bonwell and Eison, 1991). This stream of research often focused on the impact of edutainment on communication, persuasion, and learning outcomes (Haytko, 2006; Kurthakoti et al, 2013; Singhal and Rogers, 2012). This study extends the blended use of educational and entertainment content to a travel consumption setting. Moreover, experiential consumption has mostly been examined qualitatively in past literature (with the exception of Arnould and Price, 1993). This study contributes to existing literature by providing empirical evidence to substantiate this line of qualitative work.

This study developed a measure for intellectual value focusing on the knowledge 
dimension, which enhanced our understanding about consumers' motivation and intention to engage in edutainment and other experience-rich consumption. The dearth of studies focusing on consumers' intellectual value presents a research gap. The intellectual perspective of experience is an inherent and essential motivation for personal growth, which is an integral part of human behavior. As our society becomes more and more cultivated, there are reasons to believe that intellectual value in consumption will play an increasingly prominent role. The recent popularity of long-form discussion and debate entertainment on various media outlets and cognitively challenging 'escape games' and e-sports games are phenomena which can be explained by the need for intellectual consumption. Indeed, this study shows the importance of including both the emotional and intellectual value. It will yield useful insight into what type of, how, and why experience-rich consumption influences consumers' purchase decisions, evaluations, satisfaction, and well-being.

Finally, this study corroborates existing research that views customer value creation and transfer as contextual rather than universalistic in nature. According to S-O-R theory, internal experience, in this case, emotional and intellectual value, is automatically transferred to an outcome (i.e., customer outcomes such as customer satisfaction and customer wellbeing). Recent research on consumers, however, suggest that value perception and appraisal is a need-based process. This need-based process reflects a service-dominant logic, which posits that value is situational and personal. Results of the current study suggest that individual differences in motivation influence the value creation process for the individual with respect to customer satisfaction and customer well-being. In particular, emotional and intellectual value are both found to be important in increasing customer satisfaction and customer wellbeing, especially for those who are more motivated in the environment afforded by the consumption context. As such, the current study offers empirical evidence to support the contingent view of value creation and transfer in consumer research. 


\subsection{Managerial implications}

Results of the current research have direct implications for the theme park and museum sectors. Theme park and museums are two equally significant revenue-generating sectors of the service and entertainment industry. In the U.S., it is estimated that museums contributed approximately USD 50 billion in 2016 to the overall economy (American Alliance of Museums, 2017). In France, it is estimated that museums contributed USD 247 million in 2010 (EGMUS, 2013). As for theme parks, attendance worldwide was growing at a rate of 5.4\% with 235.6 million estimated visits for the top 25 theme parks (Global Attractions Attendance Report, 2015) and it is estimated that in Europe, the theme park industry generated around USD 5.3 billion in total revenue in 2013 (IAAPA, 2017). Beneath this substantial revenue at the aggregate level, individual theme parks and museums are tirelessly trying to adapt their attractions and exhibitions to differentiate from themselves from their competitors domestically and abroad. One takeaway from the current research is that both theme parks and museums could adopt the edutainment model and invest in attractions and exhibitions that offer a good balance of emotional (fun) as well as intellectual (stimulating) value. Perhaps an emotionally-arousing roller coaster ride is best combined with an intellectually-challenging 'escape game' at a theme park to generate more satisfied customers and at the same time, produce a transformative experience that would enhance customer wellbeing. Moreover, maybe an intellectually-stimulating presentation of historical information and artefacts is more memorable when coupled with a fun game designed to encourage interaction with the exhibits, other museum-goers, and staff.

As mentioned at the outset, value creation is the key success factor for companies (Carù and Cova, 2006; Sweeney and Soutar, 2001). Adding intellectual value on top of emotional value is one way for companies to enhance the value of their products. This would 
enable them to outperform competitors and to differentiate their products and services. The current study provides managerial insight enabling companies to better cater to consumers' ever-growing demand for experiential consumption. Businesses looking to enhance consumer experience may consider adopting the edutainment model emphasizing both learning and entertainment, and introduce whichever aspect is lacking to better serve customers. For instance, many brick-and-mortar retailers are trying to create more engaging in-store experiences to compete with the growing online retail industry. These brick-and-mortars are keen on using technologies to create novel and more interactive shopping experiences for the customers. One of the challenges that these physical retailers are facing is to ensure that technology is incorporated in-store in meaningful ways rather than superficially as gimmicks. Drawing on results from the current paper, an experience that yields both emotional and intellectual value will contribute not only to customer satisfaction but also to customer wellbeing...provided the experience is considered relevant to the customer. Technology should therefore be incorporated to generate both emotional (fun) and intellectual (stimulating) value to their target markets. In addition, the current study showed that the under-examined intellectual value has independent and substantial effects on customer satisfaction, and in turn, revisit intention for highly motivated (high personal relevance) individuals for a given consumption context. These results can be interpreted as initial evidence that - for companies that deploy a niche market targeting strategy, or those able to identify and target a sub-group of highly motivated customers - investment in technology and experience geared toward creating intellectual value may help enhance customer experience as well as generate additional streams of revenue. For instance, the emergence and prevalence of 'escape games' (also known as 'escape room' which is an adventure that requires its participants to solve puzzles and riddles in a given time and physical environment) could be one form of an intellectually stimulating consumer experience that can be created out of many theme parks, 
museums, and even retail venues.

Finally, results suggest that the entertainment business can influence consumer wellbeing by implementing the right service and experience design. Marketing research that examines well-being usually focus on the relationship between materialism and well-being. In general, these studies seem to suggest that materialism would harbor long-term negative consequences for the society and the individual (Burroughs and Rindfleisch, 2002). Recent studies found that people are generally happier with their experiential purchases than material ones (Nicolao et al, 2009). Apparently, consumer experience is not only an important differentiation tool for companies, it also contributes to the welfare of consumers and society at large. Designing edutainment consumption, or a consumption experience that offers a balance of emotional and intellectual value, is perhaps a more sustainable growth model.

\subsection{Limitations and future research}

The current study focused on an edutainment consumption context, namely, an amusement park-museum with a biblical theme. The generalizability of the intellectual value measure to other contexts, such as dining, online shopping, museum and exhibition, advertising, and airline, can enhance its validity. Research has shown that extended experiences can take on different patterns, such as increasing in intensity or adaptation (Ariely and Zauberman, 2003). These patterns can affect how experiences are evaluated. As such, it may be interesting to explore how emotional and intellectual values contribute to the overall enjoyment of the experience at different phases of the extended experience. Related to this point is the fact that all data in the current study were collected in a retrospective manner. Future research may investigate whether retrospective experiences are different from dynamic, instantaneous experiences. Moreover, the data from this study were all collected from a Chinese population, namely, from Hong Kong. Could there be a cultural difference 
regarding how people perceive experiential value? Or how do these values influence other consumer behavior? These questions await future studies.

Moreover, intellectual value is conceptualized as the knowledge dimension of selfgrowth and self-enhancement. It is not a comprehensive intellectual value measure that would capture the whole spectrum of non-utilitarian cognitive value, especially for more complex and prolonged forms of edutainment. The knowledge dimension of intellectual value is the focus of this study, because one of the objectives of this research is to offer a measure for intellectual value, which can be generalized to common consumption contexts. But future studies should explore other higher-order cognition such as knowledge integration and generation (Krathwohl, 2002; Sosniak, 1994), to gain further understanding of other aspects of intellectual value in the consumption process.

The current study used self-reported religious affiliation (i.e., bible-based vs. non bible based) as a proxy for an individual's sense of personal relevance with the consumption context (i.e., Christian bible-themed park-museum). The dichotomous nature of this personal relevance measure may have limited the findings because everyone in the same level of the categorization (i.e., affiliated with a bible-based vs. not affiliated with a bible-based) was treated. This operationalization does not allow for a test to assess how variations in participation in a religion (e.g., a believer, a practitioner, etc.) may further impact one's motivation, and in turn, the value creation and transfer process. To extend our understanding of this construct, future studies may operationalize personal relevance as a multi-categorical variable or a continuous variable such as involvement and consumer expertise. In addition, intellectual value has been found to have an impact on both customer satisfaction and customer well-being, but only for those who are in the high personal relevance group. Since the setting where data was collected in the current research entails biblical events and preaching, these results can be interpreted as that individuals who are affiliated with 
Christianity may be more motivated to engage cognitively with the park-museum and thus derive a positive experience from the facility and with themselves. Future studies may expand our understanding about the impact of intellectual value to test other consumption contexts, including other forms of cognitive involvement, such as different interests, knowledge bases, and general cognitive ability levels.

Finally, many have suggested that customer engagement is a critical factor for customer satisfaction and loyalty (e.g., Carù and Cova, 2006). Designing an experience that offers both emotional and intellectual value can also be viewed as creating an engaging customer experience. Customer engagement is defined as 'a psychological state that occurs by virtue of interactive, co-creative customer experiences with a focal agent/object (e.g., a brand)' (Brodie and Hollebeek, 2011, p. 790). Moreover, the strength of engagement refers to 'a state of being involved, occupied, fully absorbed, or engrossed in something' (Higgins and Scholer, 2009, p. 112). In the marketing literature, customer engagement behavior is conceptualized as a prolonged experience represented by interactions and co-creations between a customer and a brand/company across different touchpoints over an extended period of time (Chen, Yu, Gentry, Yu, 2016; Greve, 2014). Taken together, experience that engages the customer both emotionally and cognitively should also be more interactive and therefore lead to one being more involved, occupied, absorbed, and engrossed. Put differently, emotional and intellectual value can also be used to guide and assess marketing efforts to enhance customer engagement. Furthermore, customer engagement has also been described to include a customer's behaviors toward a brand beyond purchases and transactions (Van Doom et al, 2000). Since emotions are often more difficult to express in words, intellectual value experienced during consumption may facilitate post-consumption sharing motivation and activity. Future studies may look at whether and how post-consumption sharing differs for edutainment, as well as adopt a longitudinal design in accessing customer engagement in 
prolonged experiences.

Finally, it is worth noting that because of the lack of literature as to how consumer well-being is related to company-related concepts such as revisit intention, it remains unclear why the current study finds that emotional and intellectual value enhances consumer wellbeing but that consumer well-being does not lead to revisit intention. This unexpected result opens a new perspective for researchers to examine if consumer well-being would have any impact on other outcomes such as brand trust and loyalty. 


\section{REFERENCES}

Addis M. 2005. New technologies and cultural consumption - edutainment is born! European Journal of Marketing 39(7/8): 729-736.

Anderson JC, Gerbing DW. 1988. Structural equation modeling in practice: a review and recommended 2-Step approach. Psychological Bulletin 103(3): 411-423.

American Alliance of Museums. 2017. Museums as Economic Engines: A National Report.

Andrews, F. M., \& Withey, S. B. (1976). Social indicators of well-being: The development and measurement of perceptual indicators. New York: Plenum.10, 978-1.

Ariely, D, Zauberman, G. 2003. Differential partitioning of extended experiences. Organizational Behavior and Human Decision Processes 91(2): 128-139.

Arnould EJ, Price, LL. 1993. River magic: extraordinary experience and the extended service Encounter. Journal of Consumer Research 20(1): 24-45.

Babin BJ, Darden WR, Griffin M. 1994. Work and/or fun: measuring hedonic and utilitarian shopping value. Journal of Consumer Research 20(4): 644-656.

Balloffet P, Courvoisier FH, Lagier J. 2014. From museum to amusement park: the opportunities and risks of edutainment. International Journal of Arts Management 16 (2): 4-18.

Bendapudi N, Leone RP. 2003. Psychological implications of customer participation in coProduction. Journal of Marketing 67(1): 14-28.

Bitner MJ. 1992. Servicescapes: the impact of physical surroundings on customers and employees. Journal of Marketing 56(2): 57-71.

Brendl CM, Markman AB, Messner C. 2003. The devaluation effect: activating a need devalues unrelated objects. Journal of Consumer Research 29: 463-73.

Brodie, RJ, Hollebeek, LD. 2011. Advancing and consolidating knowledge about customer engagement. Journal of Service Research 14(3): 283-284.

Burroughs JE, Rindfleisch A. 2002. Materialism and well-being: a conflicting values perspective. Journal of Consumer Research 29(3): 348-370.

Byrne BM. 2004. Testing for multigroup invariance using AMOS graphics: A road less traveled. Structural Equation Modeling 11(2): 272-300.

Carù, A, Cova, B. 2006. How to facilitate immersion in a consumption experience: appropriation operation and service elements. Journal of Consumer Behavior 5(1): 414.

Chartrand TL, Huber J, Shiv B, Tanner RJ. 2008. Nonconscious goals and consumer choice. 
Journal of Consumer Research 35(2), 189-201.

Chen, Y. 2009. Possession and access: consumer desires and value perceptions regarding contemporary art collection and exhibit visits. Journal of Consumer Research 35(6): 925-940.

Chen, X, Yu, H, Gentry, JW, \& Yu, F. 2017. Complaint or recommendation? The impact of customers' state and trait goal orientations on customer engagement behaviors. Journal of Consumer Behaviour, 16(2), 187-194.

Correia Loureiro SM, Almeida M, RP. 2013. The effect of atmospheric cues and involvement on pleasure and relaxation: the spa hotel context. International Journal of Hospitality Management 35: 35-43.

Correia Loureiro SM, Kastenholz E. 2011. Corporate reputation, satisfaction, delight, and loyalty towards rural lodging units in Portugal. International Journal of Hospitality Management 30(3): 575-583.

Diener, E., Oishi, S., \& Lucas, R. E. (2003). Personality, culture, and subjective well-being: Emotional and cognitive evaluations of life. Annual Review of Psychology, 54(1), 403425.

Easterlin, R. A. (2003). Explaining happiness. Proceedings of the National Academy of Sciences, 100(19), 11176-11183.

European Group on Museum Statistics (EGMUS) (2015), "Statistics," Europe (available at www.egmus.eu/en/statistics/).

Eventbrite. 2014. Millennials: fueling the experience economy. (available at https://eventbrites3.s3.amazonaws.com/marketing/Millennials_Research/Gen_PR_Fin al.pdf)

Fornell C, Larcker DF. 1981. Evaluating structural equation models with unobservable variables and measurement error. Journal of Marketing Research 18(1): 39-40.

Frank, R. H. (1985). The demand for unobservable and other nonpositional goods. American Economic Review, 75(1), 101-116.

Frijda, NH. 1986. The Emotions, NY: Cambridge University Press.

Frey, B. S. \& Stutzer, A. (2002). Happiness and Economics: How the Economy and Institutions Affect Human Well-being, Princeton, NJ: Princeton University Press.

Gallarza MG, Fayos Gardó T, Calderón García H. 2016. Experiential tourist shopping value: adding causality to value dimensions and testing their subjectivity. Journal of Consumer Behavior 16: 76-92.

Greve, G. 2014. The moderating effect of customer engagement on the brand image-brand 
loyalty relationship. Procedia-Social and Behavioral Sciences, 148, 203-210.

Theme Entertainment Association. 2017. Theme index and museum index: the global attractions attendance report.

Gorn, GJ, Goldberg, ME, Basu, K. 1993. Mood, awareness, and product evaluation. Journal of Consumer Psychology 2(3), 237.

Haytko DL, Baker J. 2004. It's all at the mall: exploring adolescent girls' experiences. Journal of Retailing 80(1): 67-83.

Heo CY, Lee S. 2009. Application of revenue management practices to the theme park Industry. International Journal of Hospitality Management 28(3): 446-453.

Higgins ET, Scholer AA. 2009. Engaging the consumer: the science and art of the value creation process. Journal of Consumer Psychology 19(2): 100-114.

Hinkin TR. 1995. A review of scale development practices in the study of organizations. Journal of Management 21(5): 967-988.

Holbrook MB, Hirschman EC. 1982. The experiential aspects of consumption: consumer fantasies, feelings, and fun. Journal of Consumer Research 9(2): 132-140.

Hong Kong: The Facts. Religion and Customs. 2016. https:/www.gov.hk/en/about/abouthk/factsheets/docs/religion.pdf

Howell, R. T. \& Hill, G. (2009). The mediators of experiential purchases: determining the impact of psychological needs on social comparison. Journal of Positive Psychology, 4(2), 511-522.

Hunt, DM, Radford, SK, Evans, KR. 2013. Individual differences in consumer value for mass Customized products. Journal of Consumer Behavior 12: 327-336.

International Council of Museums. 2007. Museum definition. U.S. (available at icom.museum/definition.html).

Jacoby J. 2002. Stimulus-organism-response reconsidered: an evolutionary step in modeling (consumer) behavior. Journal of Consumer Psychology 12(1): 51-58.

Jani D, Han H. 2015. Influence of environmental stimuli on hotel customer emotional response: testing the moderating effect of the big five personality factors. International Journal of Hospitality Management 44: 48-57.

Joy A, Sherry JF. 2003. "Speaking of art as embodied imagination: a multisensory approach to understanding aesthetic experience. Journal of Consumer Research 30(2): 259-282.

Kim WG, Moon YJ. 2009. Customers' cognitive, emotional, and actionable response to the servicescape: a test of the moderating effect of the restaurant type. International Journal of Hospitality Management 28(1): 144-156. 
Kozak M, Rimmington M. 1999. Measuring tourist destination competitiveness: conceptual considerations and empirical findings. Hospitality Management 18(3): 273283.

Krathwohl, D. R. 2002. A revision of Bloom's taxonomy: An overview. Theory into practice, 41(4), 212-218.

Laran J, Janiszewski C, Cunha Jr., M. 2008. Context-dependent effects of goal primes. Journal of Consumer Research 35(4): 653-67.

Lucas, R. E., Diener, E., \& Suh, E. (1996). Discriminant validity of well-being measures. Journal of Personality and Social Psychology, 71(3), 616.

Maslow AH. 1954. Motivation and Personality, New York: Harper and Row.

Mathwick C, Malhotra N, Rigdon, E. 2001. Experiential value: conceptualization, measurement and application in the catalog and internet shopping environment. Journal of Retailing 77: 39-56.

McCue TJ. 2015. Online learning industry poised for $\$ 107$ billion in 2015 . Forbes (available at http://www.forbes.com/sites/tjmccue/2014/08/27/online-learningindustry-poised-for-107-billion-in-2015/\#4e71e6f66bcc)

Mehrabian A, Russell JA. 1974. An Approach to Environmental Psychology, Cambridge, MA: MIT Press.

Mick DG, Pechmann PS, Ozanne JL. 2012. Transformative Consumer Research for Personal and Collective Well-being, New York: Routledge: 3-24.

Moal-Ulvoas, G, Taylor, VA. 2014. The spiritual benefits of travel for senior tourists. Journal of Consumer Behavior 13: 453-462.

Mochon, D., Norton, M. I., \& Ariely, D. (2008). Getting off the hedonic treadmill, one step at a time: The impact of regular religious practice and exercise on well-being. Journal of Economic Psychology, 29(5), 632-642.

Nicolao L, Irwin JR, Goodman JK. 2009. Happiness for Sale: Do experiential purchases make consumer happier than material purchases. Journal of Consumer Research 36(2): 188-198.

Novak TP, Hoffman DL, Yung YF. 2000. Measuring the customer experience in online environments: a structural modeling approach. Marketing Science 19(1): 22-42.

Nunnally J. 1978. Psychometric Theory, New York: McGraw-Hill.

Oliver RL, Bearden WO. 1985. Disconfirmation processes and consumer evaluations in product usage. Journal of Business Research 13(3): 235-246.

Pham MT. 1998. Representativeness, relevance, and the use of feelings in decision Making. Journal of Consumer Research 25(2): 144-159. 
Schervish, P., \& Szanto, A. (2006). Wealth and giving by the numbers. Reflections, 2, 30-49.

Schwarz N. 1990. Feelings as information: informational and motivational function of affective states. Guilford Press.

Seth JN, Newman BI, Gross BL. 1991. Why we buy what we buy: a theory of consumption values. Journal of Business Research 22(2): 159-170.

Singhal A, Rogers EM. 2002. A theoretical agenda for entertainment-education. Communication Theory 12(2): 117-135.

Sheldon KM, Elliot AJ, Kim Y, Kasser T. 2001. What's satisfying about satisfying events? comparing ten candidate psychological needs. Journal of Personality and Social Psychology 80(2): 325-339.

Sheng CW, Chen MC. 2012. A study of experience expectations of museum visitors. Tourism Management 33: 53-60.

Shoham A, Rose GM, Kahle LR. 1998. Marketing of risky sports: from intention to action. Journal of the Academy of Marketing Science 26(4): 307-321.

Sosniak, LA (1994). Bloom's taxonomy. L. W. Anderson (Ed.). Univ. Chicago Press.

Sweeney JC, Soutar GN. 2001. Consumer perceived value: the development of a multiple item scale. Journal of Retailing 77(2): 203-220.

The International Association of Amusement Parks and Attractions (IAAPA). 2015. Amusement park and attractions industry statistics. U.S. (available at www.iaapa.org/resources/bypark-type/amusement-parks-and-attractions/industrystatistics).

Thomson M, MacInnis DJ, Park CW. 2005. The ties that bind: measuring the strength of consumers' emotional attachments to brands. Journal of Consumer Psychology 15(1): 77-91.

Tribe J, Liburd JJ. 2016. The tourism knowledge system. Annals of Tourism Research, 57, 4461.

Troye SV, Supphellen M. 2012. Consumer participation in coproduction: I made it myself effects on consumers' sensory perceptions and evaluations of outcome and input product. Journal of Marketing 76(2): 33-46.

Unger LS, Kernan JB. 1983. On the meaning of leisure: an investigation of some determinants of the subjective experience. Journal of Consumer Research 9(4): 381-392.

Van Boven, L., \& Gilovich, T. (2003). To do or to have? That is the question. Journal of Personality and Social Psychology, 85(6), 1193.

Van Doorn J, Lemon KN, Mittal V, Nass S, Pick D, Pirner P, Verhoef PC. 2010. Customer 
engagement behavior: theoretical foundations and research directions. Journal of Service Research 13(3): 253-266.

Van Osselaer SMJ, Janiszewski C. 2012. A goal-based model of product evaluation and choice. Journal of Consumer Research 39 (2): 260-92.

Vargo SL, Lusch RF. 2008. Service-dominant logic: continuing the evolution. Journal of the Academy Marketing Science 36(1): 1-10.

Veenhoven, R. (1993). Happiness as an indicator in social policy evaluation: Some objections Considered.

Wakefield KL, Blodgett JG. 1994. The importance of servicescapes in leisure service settings. Journal of Services Marketing 8(3): 66-76.

Zeithaml VA. 1988. Consumer perceptions of price, quality, and value: a means-end model and synthesis of evidence. Journal of Marketing 52(3): 2-22.

Zinnbauer BJ, Pargament KI, Cole B, Rye MS, Butter EM, Belavich TG, Hipp KM, Scott AB, Kadar JL. 1997. Religion and spirituality: unfuzzying the fuzzy. Journal for the Scientific Study of Religion 36: 549-564. 
Table 1

Main Study (N=179): Demographic Information of Visitors

\begin{tabular}{|c|c|c|c|c|c|}
\hline Variables & $\begin{array}{c}\begin{array}{c}\text { None or } \\
\text { non-bible } \\
\text { based }\end{array} \\
(\mathbf{n}=82 \\
\mathbf{4 5 . 8 \%})\end{array}$ & $\begin{array}{l}\text { Bible- } \\
\text { based } \\
(n=97 ; \\
54.2 \%)\end{array}$ & $\begin{array}{c}\text { Total } \\
(\mathrm{N}=179)\end{array}$ & $\begin{array}{c}\text { Percentage } \\
\text { (Total } \\
\text { Sample) }\end{array}$ & $\begin{array}{c}\text { Pearson } \\
\text { Chi-Square } \\
\text { value } \\
\\
\text { (Asymp. } \\
\begin{array}{c}\text { Significance } \\
\text { value) }\end{array} \\
\end{array}$ \\
\hline $\begin{array}{l}\text { Gender } \\
\text { Male } \\
\text { Female }\end{array}$ & $\begin{array}{l}27 \\
55\end{array}$ & $\begin{array}{l}35 \\
64\end{array}$ & $\begin{array}{c}62 \\
117\end{array}$ & $\begin{array}{l}34.6 \\
65.4\end{array}$ & $\begin{array}{c}1.73 \\
(p=.79)\end{array}$ \\
\hline $\begin{array}{l}\text { Age } \\
\begin{array}{l}15-19 \\
20-34 \\
34-49 \\
50-59 \\
60 \text { or above }\end{array}\end{array}$ & $\begin{array}{c}6 \\
37 \\
36 \\
3 \\
0\end{array}$ & $\begin{array}{c}3 \\
38 \\
38 \\
13 \\
5\end{array}$ & $\begin{array}{c}9 \\
75 \\
74 \\
16 \\
5\end{array}$ & $\begin{array}{c}5 \\
41.9 \\
41.3 \\
8.9 \\
2.8\end{array}$ & $\begin{array}{c}4.19 \\
(p=.38)\end{array}$ \\
\hline $\begin{array}{l}\text { Education } \\
\text { No high school } \\
\text { High school } \\
\text { Tertiary education } \\
\text { Bachelor's degree }\end{array}$ & $\begin{array}{c}1 \\
41 \\
14 \\
26\end{array}$ & $\begin{array}{c}4 \\
42 \\
15 \\
36\end{array}$ & $\begin{array}{c}5 \\
83 \\
29 \\
62\end{array}$ & $\begin{array}{c}2.8 \\
46.1 \\
16.1 \\
34.4\end{array}$ & $\begin{array}{c}5.80 \\
(p=.37)\end{array}$ \\
\hline $\begin{array}{l}\text { Monthly Income } \\
\text { (HKD\$) } \\
\text { Less than } \$ 5,000 \\
\$ 5,000-\$ 12,000 \\
\$ 12,001-\$ 25,000 \\
\$ 25,001-\$ 45,000 \\
\$ 45,001-\$ 60,000 \\
\$ 60,001-\$ 80,000 \\
\text { Above } \$ 80,000 \\
\text { Missing }\end{array}$ & $\begin{array}{l}14 \\
14 \\
20 \\
11 \\
2 \\
4 \\
9 \\
8\end{array}$ & $\begin{array}{c}13 \\
14 \\
32 \\
19 \\
2 \\
4 \\
6 \\
7\end{array}$ & $\begin{array}{c}27 \\
28 \\
52 \\
30 \\
4 \\
8 \\
15 \\
15\end{array}$ & $\begin{array}{l}15.1 \\
15.6 \\
29.1 \\
16.8 \\
2.2 \\
4.5 \\
8.4 \\
8.4\end{array}$ & $\begin{array}{c}6.35 \\
(p=.50)\end{array}$ \\
\hline
\end{tabular}


Table 2

Item Generation and Reduction for Intellectual Value

\begin{tabular}{|c|c|c|}
\hline Source & Construct (No. of Items) & Item \\
\hline \multicolumn{3}{|c|}{ Intellectual Value (31) } \\
\hline Arnould \& Price (1993) & $\begin{array}{l}\text { Personal Growth and } \\
\text { Renewal (6): }\end{array}$ & $\begin{array}{l}\text { I had a sense of adventure } \\
\text { I was personally challenged } \\
\text { I had an adrenalin rush } \\
\text { I learned new things } \\
\text { I mastered new skills } \\
\text { I tested my limits }\end{array}$ \\
\hline \multirow[t]{2}{*}{ Chen (2009) } & Access Value (3): & $\begin{array}{l}\text { I was inspired to imagine } \\
\text { My ideas were changed } \\
\text { My mind was opened }\end{array}$ \\
\hline & Possession Values (1) & I preserved something important \\
\hline \multirow[t]{2}{*}{$\begin{array}{l}\text { Novak, Hoffman, \& } \\
\text { Yung (2000) }\end{array}$} & Challenge (4): & $\begin{array}{l}\text { I was challenged } \\
\text { I was challenged to perform to the best of my } \\
\text { ability } \\
\text { I was tested of my skills } \\
\text { My capabilities were stretched to my limits }\end{array}$ \\
\hline & Exploratory Behavior (1): & I enjoyed the unfamiliarity \\
\hline $\begin{array}{l}\text { Shoham, Rose \& Kahle } \\
\text { (1998) }\end{array}$ & Curiosity-Arousal (3): & $\begin{array}{l}\text { I knew more } \\
\text { I found out how I felt after I participated } \\
\text { I was interested }\end{array}$ \\
\hline \multirow[t]{2}{*}{ Unger \& Kernan (1983) } & Mastery (4): & $\begin{array}{l}\text { I felt like I was conquering the world } \\
\text { I had a sense of risk } \\
\text { I felt like a real champion } \\
\text { I felt that I have been thoroughly tested }\end{array}$ \\
\hline & Arousal (3): & $\begin{array}{l}\text { My sense of curiosity was satisfied } \\
\text { I had novel experiences } \\
\text { I felt like I was exploring new worlds }\end{array}$ \\
\hline Focus Group & (6) & $\begin{array}{l}\text { I observed something new } \\
\text { I obtained some important information } \\
\text { I obtained some interesting information } \\
\text { I saw something new } \\
\text { I tried something new } \\
\text { I widened my knowledge }\end{array}$ \\
\hline
\end{tabular}


Table 3

Pilot Study (N =120): Initial Exploratory Factor Analysis (Varimax Rotation)

Rotated Component Matrix

\begin{tabular}{|c|c|c|c|c|}
\hline & \multicolumn{4}{|c|}{ Component } \\
\hline & 1 & 2 & 3 & 4 \\
\hline I obtained interesting information & 0.81 & & & \\
\hline I learned new things & 0.77 & & & \\
\hline I widened my knowledge & 0.76 & & & \\
\hline I knew more & 0.74 & & & \\
\hline I saw something new & 0.71 & & & \\
\hline My mind was opened & & 0.85 & & \\
\hline My sense of curiosity was satisfied & & 0.84 & & \\
\hline I had novel experience & & 0.75 & & \\
\hline I was inspired to imagine & & & 0.73 & \\
\hline I was tested of my skills & & & & 0.91 \\
\hline My capabilities were stretched to my limits & & & & 0.84 \\
\hline
\end{tabular}


Table 4

Main Study ( $N=179)$ : Confirmatory Factor Analysis of Variables

\begin{tabular}{|c|c|c|c|c|}
\hline Construct & Item & $\begin{array}{l}\text { Standardized } \\
\text { factor loadings }\end{array}$ & $\begin{array}{c}\text { Cronbach's } \\
\text { Alpha }\end{array}$ & AVE \\
\hline $\begin{array}{l}\text { Emotional Value } \\
\text { (Sweeney \& Soutar, } \\
\text { 2001) }\end{array}$ & 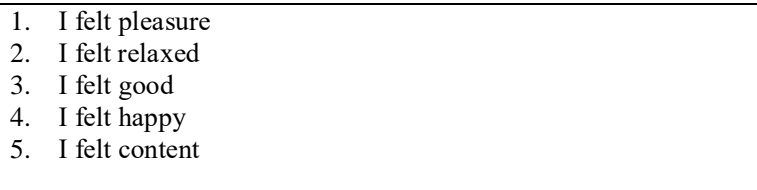 & $\begin{array}{l}0.89 \\
0.84 \\
0.93 \\
0.94 \\
0.89\end{array}$ & .95 & 0.90 \\
\hline $\begin{array}{l}\text { Intellectual Value } \\
\text { (Developed for the } \\
\text { purpose of this } \\
\text { study) }\end{array}$ & $\begin{array}{l}\text { 1. I learned new things } \\
\text { 2. I widened my knowledge } \\
\text { 3. I saw something new } \\
\text { 4. I obtained interesting information } \\
\text { 5. I knew more }\end{array}$ & $\begin{array}{l}0.83 \\
0.92 \\
0.89 \\
0.92 \\
0.92\end{array}$ & .95 & 0.90 \\
\hline $\begin{array}{l}\text { Edutainment } \\
\text { Performance } \\
\text { (Kim \& Moon, } \\
\text { 2009) }\end{array}$ & $\begin{array}{l}\text { 1. The buildings/décor of the site were attractive } \\
\text { 2. The site had appropriate music in keeping with its atmosphere } \\
\text { 3. The attractions/activities in the site were interactive } \\
\text { 4. The attractions in the site had variety }\end{array}$ & $\begin{array}{l}0.79 \\
0.79 \\
0.85 \\
0.89\end{array}$ & .88 & 0.83 \\
\hline $\begin{array}{l}\text { Customer } \\
\text { Satisfaction } \\
\text { (Oliver \& Bearden, } \\
\text { 1985) }\end{array}$ & $\begin{array}{l}\text { 1. I was satisfied with my experience at the site. } \\
\text { 2. I was satisfied with the site } \\
\text { 3. I would say this was an excellent experience }\end{array}$ & $\begin{array}{l}0.88 \\
0.95 \\
0.92\end{array}$ & .94 & 0.92 \\
\hline $\begin{array}{l}\text { Customer well- } \\
\text { being } \\
\text { (Adapted from } \\
\text { Arnould \& Price, } \\
\text { 1993; Sheldon et al, } \\
\text { 2001) }\end{array}$ & $\begin{array}{l}\text { 1. I had a sense of self-growth } \\
\text { 2. I got a new perspective on myself } \\
\text { 3. I rediscovered what really matters } \\
\text { 4. I had a sense of self-respect }\end{array}$ & $\begin{array}{l}0.81 \\
0.84 \\
0.93 \\
0.95\end{array}$ & .93 & 0.88 \\
\hline $\begin{array}{l}\text { Revisit } \\
\text { (Kim \& Moon, } \\
\text { 2009) }\end{array}$ & $\begin{array}{l}\text { 1.I would like to revisit this site in the near future } \\
\text { 2.I would like to bring my family and friends to this site } \\
\text { 3. This park would be my first choice over others }\end{array}$ & $\begin{array}{l}0.84 \\
0.96 \\
0.94\end{array}$ & .92 & 0.91 \\
\hline
\end{tabular}


Table 5

Main Study (N = 179): Comparison of AVE and Squared Correlations of Paired Constructs

\begin{tabular}{lcccccc}
\multicolumn{1}{c}{ Constructs } & $\mathbf{1}$ & $\mathbf{2}$ & $\mathbf{3}$ & $\mathbf{4}$ & $\mathbf{5}$ & $\mathbf{6}$ \\
\hline 1. Edutainment Performance & $\mathbf{0 . 8 3}$ & & & & & \\
2. Emotional Value & 0.58 & $\mathbf{0 . 9 0}$ & & & & \\
3. Intellectual Value & 0.56 & 0.69 & $\mathbf{0 . 9 0}$ & & & \\
4. Customer Satisfaction & 0.66 & 0.79 & 0.62 & $\mathbf{0 . 9 2}$ & & \\
5. Customer well-being & 0.49 & 0.38 & 0.48 & 0.49 & $\mathbf{0 . 8 8}$ & \\
6. Revisit & 0.64 & 0.72 & 0.59 & 0.77 & 0.45 & $\mathbf{0 . 9 1}$ \\
\hline
\end{tabular}

Note: AVE is on the diagonal. Squared correlations of paired constructs are on the off-diagonal. 
Table 6

Main Study ( $=179)$ : Structural Parameter Estimates of the Conceptual Model

\begin{tabular}{|c|c|c|c|}
\hline Hypothesized path & Standardized path coefficient & t-value & Results \\
\hline \multicolumn{4}{|l|}{ H1 } \\
\hline a: Edutainment performance $\rightarrow$ emotional value & 0.78 & $10.35^{* *}$ & Supported \\
\hline b: Edutainment performance $\rightarrow$ intellectual value & 0.77 & $9.54 * *$ & Supported \\
\hline \multicolumn{4}{|l|}{$\mathrm{H} 2$ : Mediation on customer satisfaction } \\
\hline a: Emotional value $\rightarrow$ customer satisfaction & 0.73 & $8.78 * *$ & Supported \\
\hline b: Intellectual value $\rightarrow$ customer satisfaction & 0.20 & $2.62 *$ & Supported \\
\hline \multicolumn{4}{|l|}{ H3: Mediation on customer well-being } \\
\hline a: Emotional value $\rightarrow$ customer well-being & 0.06 & n. s. & Not supported \\
\hline b: Intellectual value $\rightarrow$ customer well-being & 0.64 & $5.43^{* * *}$ & Supported \\
\hline \multicolumn{4}{|l|}{$\mathrm{H} 4$} \\
\hline a: Customer satisfaction $\rightarrow$ revisit & 0.95 & $14.39 * * *$ & Supported \\
\hline b: Customer well-being $\rightarrow$ revisit & 0.07 & n. s. & Not supported \\
\hline
\end{tabular}




\section{Table 7}

Main Study ( $=179)$ : Testing for Equality Across Personal Relevance Groups Results of a Multi-group Comparison Test

\begin{tabular}{lllll}
\hline & $\chi^{2}(d f)$ & $\chi^{2}$ difference & $\Delta d f$ & $p$-value \\
\hline Model 0 (Constrained model) & $976.11(544)$ & -- & --- & --- \\
Model 1 (Constrained paths model) & $976.04(536)$ & 0.07 & 8 & $p>.1$ \\
Model 2 (Freed paths model) & & & & \\
& $957.70(526)$ & 18.34 & 10 & $p<.05$ \\
& & & & \\
\hline
\end{tabular}


Table 8

Main Study ( $=179)$ : Multi-group Analysis: Structural Parameter Estimates

$\begin{array}{lcc}\text { Hypothesized path } & \begin{array}{c}\text { Standardized path coefficient } \\ \text { (t-value) }\end{array} & \text { Results }\end{array}$

H4: Personal Relevance will moderate the relationships described in

Personal Relevance Low (t-value)

a) $\mathrm{H} 2$ and b) $\mathrm{H} 3$.

H2: Mediation on customer satisfaction

a: Emotional value $\rightarrow$ customer satisfaction

$0.68(6.73)$

0.10 (n.s.)

$0.80(7.77)$

b: Intellectual value $\rightarrow$ customer satisfaction

0.02 (n.s.)

a: Emotional value $\rightarrow$ customer well-being

$0.47(5.41)$

$0.31(3.87)$

Supported

b: Intellectual value $\rightarrow$ customer well-being 
Figure 1

Stimulus-Organism-Response Framework

\begin{tabular}{c} 
Stimulus: \\
$\begin{array}{c}\text { Encountered Environment } \\
\text { (Immediate Surrounding) }\end{array}$ \\
\hline \begin{tabular}{c|} 
Organism: \\
Experience through the \\
emotive and cognitive systems
\end{tabular} \\
\hline Responses: \\
Inward \\
(e.g., learning, change in feelings, beliefs) \\
Outward \\
(e.g., non-verbal, verbal, behavioral)
\end{tabular}


Figure 2

Conceptual Framework Proposed by the Current Study

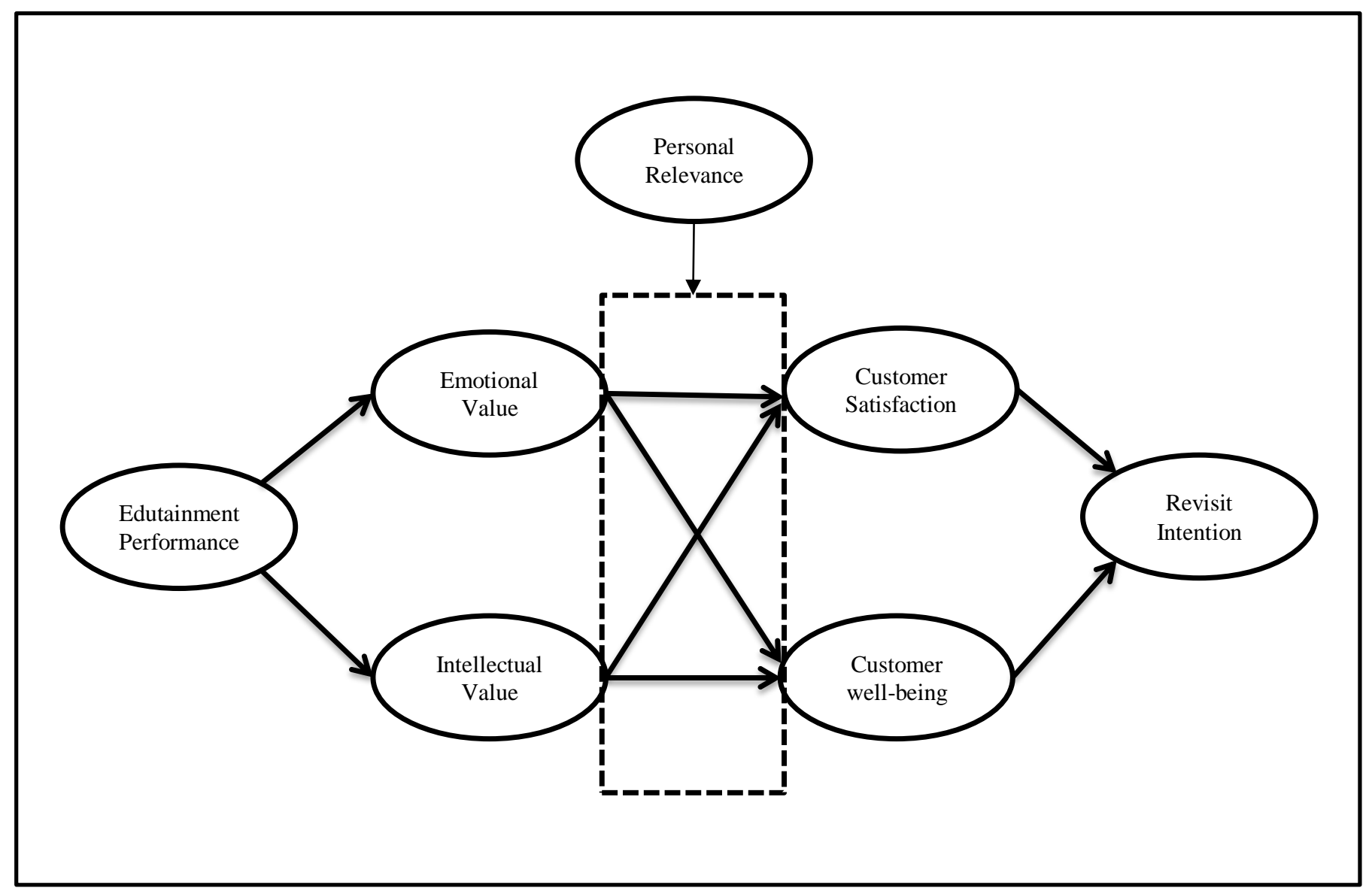

